Ukrainian sense. 2020. ISSN 2313-4437

UDK $81 ’ 25$

DOI $10.15421 / 462002$

\title{
MAIN TYPES OF AMERICAN SLANG AND ITS TRANSLATION INTO UKRAINIAN
}

O. Hurko

Doctor of Philology, Associate Professor, Head of English Language Department for Non-Philological Specialities, Oles Honchar Dnipro National University hurko.o.v@gmail.com orcid.org/0000-0002-2839-2400

Introduction. Today, issues related to the study of slangisms are gaining new perspectives as slang is becoming an integral part of modern linguistics. Slangisms gradually become part of the language, function in it, and then disappear, giving opportunity new ones to exist (so new slang expressions can be formed). However, American slang is peculiar and unique, created in different social and age groups as a desire for brevity and expressiveness, sometimes as a protest against long words or as a desire to name an object or its properties in its own way. Therefore, considering the fact that linguistics of the $21 \mathrm{st}$ century is characterized by a tendency to analyze live communication, and oral language communication is still the most important aspect of language, we consider the study of American slang and the identification of its major groups to be relevant at the present stage of the development of linguistics and translation. The problem of the study of slang in domestic and foreign linguistics has been studied by such linguists as I. Galperin (Galperin, 2014), S. Yermolenko, S. Bybyk and O. Todor (Yermolenko, Bybyk \& Todor, 2001), T. Zakharchenko (Zakharchenko, 2009), V. Dorda (Dorda, 2012), L. Stavytska (Stavytska, 2013), N. Shulzhuk (Shulzhuk, 2010) etc. Although the term slang was first recorded in the eighteenth century in the English language, there are a large number of conflicting defenitions of this term in linguistic literature. S. Yermolenko, S. Bybyk and O. Todor define slang as "a variant of professional language, words and expressions used in communication between people of different age groups, professions, social strata" (Yermolenko, 2001: 160). L. Stavitskaya notes that "slang is the type of language used in informal situations when it's comfortable for people to communicate with each other (friends, colleagues, family), and they will understand it correctly for sure. Such 'no tie' language often makes the conversation 'warmer' and brings people closer together" (Stavytska, 2013: 15). The authors of the New Oxford Dictionary of English define slang as "poken language, which is considered below the standard of the language of educated people, consisting of new or common words used in special meanings, as well as a set of special lexemes used by a group of people who belong to the lower classes of society and have a bad reputation" (The New Oxford Dictionary of English, 2005). On the other hand, I. Galperin generally denies the fact that slang functions as a separate independent category and proposes to use the term 'slang' as a synonym, the English equivalent of jargon (Galperin, 2014: 106). Thus, slang is a vivid, expressive component of non-literary vocabulary, encompassing different words and phrases with the help of which people can be identified to certain social and professional groups. That is why the object of our article is American slangisms. In our scientific study we aim to investigate the specifics of using American slangisms. The goal is to perform the following tasks: to analyze the main types of American slangisms and their equivalents in the Ukrainian language and to identify the sentences in which youth slang units are available. The study was based on slangs taken from English dictionaries and social networks.

Methods and methodology of investigation. In the context of studies, a descriptive method was used, which made it possible to theoretically generalize the results, systematize and interpret the functioning of slang units at a particular stage of language development, continuous sampling method was used to distinguish modern American slang units from the total number of lexemes as 


\section{Ukrainian sense. 2020. ISSN 2313-4437}

well as the method of translation transformations to achieve the adequate transmission of the content of these slangisms.

Results and discussion. Scientists mainly distinguish two types of slang - general and special. However, there is currently no unanimity in distinguishing between special slang. Some researchers believe that special slang encompasses argo, kent, rhyming slang, social jargon and professional speeches, back slang (Bulyko, 2007: 69). Others are convinced that special slang is a specific vocabulary and phraseology of social jargon, professional speeches, and the argo of the criminal world (Gorshunov, 2012: 10). However, in our opinion, special slang is basically a national phenomenon that has no analogues in another culture. Therefore, within our study we distinguish 4 types of slang: 1) rhyming slang; 2) mobile slang; 3) student slang; 4) everyday slang.

Rhyming slang is one of the atypical types of English-language slang that originated in the East End of London in about the 1840s. The idea of rhyming slang is the use of a rhyming phrase, usually from the other two lexemes, instead of some other words, which makes it difficult to understand the expression. If we take the outdated Cockney expression 'apples and pears' as an example, the keyword will be 'pears', which rhymes with 'stairs', which implies the true meaning of the expression. To complicate interpretation, the expression 'apples and pears' is partly reduced to 'apples', for example: 'up the apples'. For example:

Dog and bone - phone (телефон);

Trouble and strife - wife (дружина);

Skin and blister - sister (cecmpa);

Adam and Eve - believe (вірити);

Mince pies - eyes (oui);

Plates of meat - feet (ноги);

Billy Button - mutton (баранина);

East and south - mouth (pom);

Barnet Fair - hair (волосся);

Ding dong - a song (пісня);

Muttonpies - eves (жінки);

Artful dodger - a lodger (квартирант);

Flea and louse - a bad house (поганий будинок);

Dan Cupid-breast (грудu);

Sorrowful tale - three months in jail (три місяиі у в'язниці).

Let's try to analyze a few expressions selected from Collins English Dictionary, which are in common English (Collins English Dictionary, 2012):

Butcher's hook - crook (ill or angry);

Oxford scholar - dollar;

Potato peeler - Sheila (a girl or young woman, a girlfriend);

Oscar Asche - cash (on behalf of Australian actor, Oscar Ash (1871-1936);

Rabbit on about something - to talk a lot (from 'rabbit and pork' - talk); Give someone a butcher's - to let someone have a look (from 'butcher's hook' - look) Use your loaf - use your head / brain (from 'loaf of bread' - head);

On one's tod - on one's own (on behalf of the famous 'Tod Sloan' jockey - own) (one by itself, separately, alone);

Take the Mickey out of someone - make fun of (from 'Mickey Bliss' - take the piss);

Elbows and kneеs - trees (літературний іменник);

Duke of Yorks - forks (сленгізм, fingers);

Richard the third - bird (slengism, girl or woman);

Not much frocks - socks;

Bees and honey - money;

Pots and pans - hands;

Errol Flynn - chin;

Gold watch - Scotch (whiskey); 


\section{Ukrainian sense. 2020. ISSN 2313-4437}

Oily rag - fag (cigarette);

Brahms and Liszt - pissed (intoxicated, drunk);

Grass park - nark (informer);

Bottle and stopper - copper (policeman);

Bird lime - time (prison);

To do birds - imprisonment.

The fast pace of life causes the emergence of new phenomena of mass nomination, in particular, the creation of complex names and the growth of abbreviations in the language. Hence the need for an adequate and economical way of transmitting information. For example, media not only 'grasp', as noted by I. Galperin, new language forms, but also expand the scope of their use (Galperin, 2014: 18).

In addition, SMS-abbreviation is nowadays functioning in almost all languages of the world, and it is used extensively to supplement the vocabulary of the language, which makes mobile slang possible.

Note that reduction is not a specific feature of an individual nation or language. SMS abbreviations are characteristic not only of English but also of other languages, and the reasons for its development should be sought not in the peculiarities of national language or national thinking, but in the general laws of the development of human society.

And it is not surprising that in our time the Internet has a great influence on the content and structure of SMS-language. The World Wide Web has its own culture and language of communication, netiquette, characters (computer geeks, mouse potatoes, screenagers (as teenagers), newbies (or noobs), technophobes). It is known that the basic principle of SMS-language is the maximum of information with the minimum number of hand-button keystrokes, that is, saving time and effort. The main features of SMS are SMS-language, chatspeak, txt, txtspk, txt talk.

The most common means of shortening words in SMS is the abbreviation and the acronym.

Common names include TTY (talk to you later); BTW (by the way); IMHO (in my humble opinion); FYI (for your information); HAND (have a nice day); V.I.P. (very important person); P.S. (from. lat. "post scriptum”); A.D. (from lat. "Anno Domini”); B.C. / B.C.E. (before Christ; before Common Era); ASAP (as soon as possible); UNO (United Nations Organization); UNESCO (United Nations Educational, Scientific and Cultural Organization); a.m. (ante meridiem, in the morning); p.m. (post meridiem, in the afternoon); i.e. (id est, that is); e.g. (exempli gratia, for example); $u$ (you); etc. (from lat. et cetera); 2G2BT (too good to be true); BZ (busy);CYT (see you tomorrow); 2moro (tomorrow); 2day (today); JIT (just in time); BD or BDAY (birthday); 2nite (tonight); 4ever (forever); AFAIK (as far as I know); RLY (really); BRB (be right back); TTYL (talk to you later); AKA (also known as); GB (good bye); TIA (thanks in advance); LOL (laugh out loud). The latter form is often used as an acronym outside of text messages.

In our study we use the classification of SMS-abbreviations presented by A. Ionina (Ionina, 2012):

1. One letter or number replaces the whole word: $b e-b$ (be); see $-s$ (see); for - 4 (four); are -r; to / too-2 (two); you -u (you); why -y; your / you are -ur.

2. One letter or number replaces the composition: activate - activ8; great-gr8 (excellent); mate - $m 8$ (comrade); later - $18 r$ (later); before - b4 (forward, before); therefore - there 4 (back); today - 2day (today); wait - w8 (wait); threesome - 3SUM (threesome); hate - H8 (hate); no one NO1 (none); anyone - NE1 (anyone); forever - 4eva (forever).

3. Changing the value of characters: $s S-\$$; oo $-\%$; tomorrow - 2moro (tomorrow); tonight - 2NITE (tonight); thanks - TX (thanks); today - 2dA (today); address - addy (addresses); says sez (say); because - cuz, bcuz, bcz, bcos, bc, coz or bcoz (because); please - plez; probably probz.

4. Reduction of letters and punctuation when:

a) are removed vowels, and the meaning of the word is determined by the sequence of vowels: between - btw (between); because - bcs (because); your - YR (yours); speak - SPK; people 
- PPL; please - pls; friend - frnd (one); homework - hmwrk (homework); message - msg (probably), peace - pce (text), text - txt (text);

b) the abbreviation are used "/": with $-w / t(c)$; something $-s / t$ (something); boyfriend $b / f$ (boyfriend); girlfriend $-g / f($ girl); bedroom $-b / r$ (bedroom); homework $-h / w$ (homework); class work $-c / w$ (class work);

c) transcription, slang or dialect are used when they are shorter than the original word, for example, instead of because - cos (because).

Modern life cannot be imagined without mail, SMS, ICQ, WhatsApp and other ways of transmitting information. However, the language of these messages is original. The creation of text messages, sms and icq is based, firstly, on the reduction of words Wd - would; secondly, the replacement of the word with one letter You - $u$; and thirdly, the replacement of letters with numbers Gr8-great; W8 -wait; 2-to, too; 4-four, for.

Communicators often disregard grammar and punctuation rules in e-mail texts. The English SMS-language is dominated by abbreviations formed by reduction of letters and punctuation. It is interesting that the SMS abbreviations are often missing vowels. For example: hi $m 8 u$ k? $i$ soz i $4 g t$ 2 cal u lst nyt-y dnt we go c film $2 \mathrm{moz}$ (60 symbols) - Hi, mate. Are you okay? I am sorry that I forgot to call you last night. Why do not we go and see a film tomorrow? (120 symbols); Sorry. BZ. CY. (10 symbols) - Sorry. Busy. See you tomorrow (23 symbols); I will be JIT. GB (12 symbols) - I will be just in time. Goodbye (24 symbols).

It should be noted that the use of such SMS-abbreviations is an acceptable phenomenon for today's society. However, we are sure that the broadcasting of such messages on national television should be prohibited, as the media must comply with the rules of literary language.

One of the major components of the English language development in recent decades has been the 'colloquialization of English', which has determined the influence of colloquial expressions on the style of communication of native speakers. That is why there are two opposite trends in the American communication system today. On the one hand, status plays an important role in the system of American values. Democratic traditions, on the other hand, require informal and symmetrical communication, which is mostly represented in student slang.

American student slang is quite heterogeneous in its genetic composition, normatively reduced, emotionally colored, functionally restricted by the linguistic subcode of a student youth socio-age group, reflecting its outlook and values (material, hedonistic, moral, and aesthetic) and performs communicative, nominative, cognitive, emotional-expressive, presentation and euphemistic functions.

In the modern language of students, there are many slang units that describe the physical and emotional state of a person caused by drug and alcohol use. This is caused not by the students' penchant for drinking, but by the desire to classify the alcoholic subculture as modern, since a person in a state of intoxication, hangover causes irony and ridicule.

Slangisms for the designation of alcoholic beverages in student speech are represented by tokens such as brew, chilly dog, brewdog, Heine, brewhaha, brewsky, sixer, twack, wouded soldier, $i$ booze, doctor, nectar. In particular, students use the following slangisms to determine the state of alcoholic or narcotic arousal: abbreviated, anchored, baked, bent, bitched, buggered, erased, faded, folded, mashed, messed, salted, sledged, thumped, zonked, zooted. For example: They give you free booze to keep you drunk. If I drive, you can keep pounding brewskie the whole time.

In addition, students also show increased interest in drugs using of which leads to 'heroic' acts. That is why they often use tokens like bud, cheba, chronic, green, jaba, leaf, Mary or Mary Jane, tree).

In modern American slang word usage, during interpersonal communication persistence (to bug somebody, nerd, tosser, square, yeah-man), captation (creep, brownnose, kiss-ass), cowardice $(N D S)$, and indecision in relations with the person of the opposite sex (chickenshit) are negatively evaluated.

Because of discipline and public order violation, students sometimes need to deal with law enforcement. This explains the presence in their speech of a number of synonyms for the name of 


\section{Ukrainian sense. 2020. ISSN 2313-4437}

the police -5-0, bacon, filth, onion, pig, po-po.

Aesthetic values which are also fixed in the lexical system of the studied sociolect have an important place in the system of perception. The leading place belongs to the sense of beauty, i.e. a beautiful girl is called mercy, betty, karena, looker.

Thus, the slang of American students clearly reflects the specifics of the social existence of its carriers, as well as the range of their interests and values that shape the outlook of the American student.

Today, we can more often see a trend of entry slang units through social networks in Ukraine and abroad, leading to the emergence of everyday slang.

The most common expressions of everyday slang among young people are:

1) to de-face - to remove someone from your account (I just de-faced that girl from my Facebook page);

2) friend-surfing - use your friends list to find new friends (He is such a loser in the real social world, but has the longest friends list on Facebook thanks to friend-surfing - mostly with fake pictures of himself);

3) to frignore - accept a friend request and later ignore a new friend (I thought this would be the beginning of a beautiful friendship, but instead of being frignored);

4) to refriend - re-add any other friend (Dang, I had to refriend him on my Facebook account. I thought I had misfriended him but he turned out to be my Math professor);

5) to defriend - remove from friends list on Facebook because you don't know the person in real life (I had to defriend this dude I thought I knew from my high school days, but it turned out I did not. He was sending me all sorts of events spam!);

6) to collect faces - add new and old friends to your Facebook account (I often do it. I regularly collect my old and new faces);

7) eager-add - find and add to friends on Facebook a person with who you have just met (Jane just got home from the bar and checked her email. She could not believe Sam had added her on Facebook already. She thought this was a bit of an eager-add);

8) profile candy - a person whose account is extremely popular (John has like 600 friends on Facebook, what with that? Nah, They're not really friends, they're just Profile Candy. Didn't ya notice most of them were hotties?);

9) facebrick - the process of adding friends to increase their number on the Internet (Your Friend: Wow you have got like 200 friends on Facebook. Me / You: Yeah but most of them are Facebricks).

Within our study, following J. Ayto and J Simpson, we distinguish groups of words that exploring the process of communicating with friends and network users (Ayto \& Simpson, 2010):

1) to facejecte - when someone on the social network sends message, writes a comment and waits for a response that doesn't always come back;

2) inbox rot - when a person leaves a friend request, and the request is being ignored. This phrase is used in situations where when someone does not want to add the user to friends but does not wish to be rude by dismissing the application;

3) to facebox - send a private message to Facebook.

Also of interest are slang verbs that serve to distinguish friends on the social network and in real life, including: irlfriend (a network user who is one in real life), like-out (evaluate all entries on any page users, using the Like sign, book-up (group of people-social network users who plan to have a meeting, chatting via Facebook), Red Cup Picture (photos that often appear on Facebook). For example: Hey Jim, my buddy just hit me up to ask if I want to go to his party this Saturday night! Is this 'Buddy' one of your Facebook friends? Well, man, I thought my irlfriend; Just looked through all of my Facebook added by others pictures. What a pleasant walk down memory lane! How many Red Cup pictures? Too many; It's like out of some fantasy novel or something, you know. Yes, you can book up to three rooms in the same booking.

The study found examples of slang expressions, when a user goes to a social networking site and does not want to, for others to see it online, and then immediately logs off: 1) prairie dogging - 


\section{Ukrainian sense. 2020. ISSN 2313-4437}

when someone visits a Facebook page just to see the news quickly and instantly logs out (Sorry, can't chat right now. Just prairie dogging it so the boss doesn't catch me using Facebook on office time); 2) to hate click - quickly exit the page to avoid replying to a person he doesn't want to talk to (Hey, did you talk to Marc today? Nope. He was gonna talk to me on Facebook, but I hate clicked him).

The conducted research makes it possible to identify the main ones characteristics of slang in the social network:

1) most of the analyzed slang expressions are related to major problems of social network users;

2) many slang statements have to do with the subculture of social network users in general and internally;

3) the main function of slang in social networks is reduction of used vocabulary.

Conclusions. Therefore, the issue of slang translation is one of the most difficult ones in translation theory. At the same time, it is important for any translator, because it is related to a number of elements, in particular, the translation variety of country studies, the culture of the translator, the availability of equivalents, context, education and knowledge of the translator. In our view, promising areas include the study of gender features in the use of American slang.

\section{REFERENCES}

Ayto, J., \& Simpson, J. (2010). The Oxford dictionaryof modern slang. Oxford: Oxford University Press.

Bulyko, A. N. (2007). Bol'shoj slovar' inostrannykh slov [A large dictionary of foreign words]. Moscow: Martin [in Russian].

Dorda, W. O. (2012). Amerykanskyi molodizhnyi slenh yak obiekt vyvchennia sotsiolinhvistyky [American youth slang as an object of study in sociolinguistics]. Materialy VI Mizhvuzivskoi konferentsii molodykh uchenykh - Proceedings of the VI Inter-University Conference of Young Scientists, 1 (pp. 77-81). Donetsk, DonNU [in Ukrainian].

Galperin, I. R. (2014). English Stylistics. Moscow: Librocom, 2014.

Gorshunov, Yu. V. (2012). Tipy smyslovykh otnoshenij mezhdu komponentami slozhnosokrashhennykh slov [Types of semantic relations between components of complex words]. St. Petersburg: Leningrad [in Russian].

Ionina, A. A. (2012). Osobennosti sovremennogo tekstovogo myshleniya. SMS-yazyk [Features of modern textual thinking. SMS language]. Moscow: Norma [in Russian].

Shulzhuk, N. W. (2011). Slenh yak neliteraturnyi plast suchasnoi ukrainskoi leksyky [Slang as a non-literary layer of modern Ukrainian vocabulary]. Naukovi zapysky Natsionalnoho universytetu "Ostrozka akademiia". Seriia "Filolohichna" - Scientific notes of the Ostroh Academy National University. Philological Series, 21, 102-112 [in Russian].

Stavitskaya, L. (2013). Problemy vyvchennia zharhonnoi leksyky: Sotsiolinhvistychnyi aspekt. [Problems in the study of jargon: Sociolinguistic aspect]. Ukrainska mova - Ukrainian Language, 1, 55-69.

The New Oxford Dictionary of English. Retrieved from: https://languages.oup.com/research/oxford-english-dictionary.

Yermolenko, S. J., Bibik, S. P., \& Todor, O. G. (2001). Ukrainska mova. Korotkyi tlumachnyi slovnyk linhvistychnykh terminiv [Ukrainian language. A short explanatory dictionary of linguistic terms]. Kyiv: Lybid [in Ukrainian].

Zakharchenko, T. E. (2009). Anglijskij i amerikanskij sleng [English and American slang]. Moscow: AST [in Russian].

\section{Анотація}

Постановка проблеми. Сьогодні питання пов'язані з вивченням сленгізмів набувають нових ракурсів студіювань, оскільки сленг стає невід'ємною частиною новітньої лінгвістики. Сленгізми поступово входять до складу мови, функиіонують в ній, а потім 


\section{Ukrainian sense. 2020. ISSN 2313-4437}

зникають, поступаючись місцем новим. Утім, американський сленг - своєрідний $i$ неповторний, народжений в різних сочіальних та вікових групах як прагнення до стислості й виразності, подекуди як протест проти довгих слів чи як бажання по-своєму назвати предмет або його властивості. Отже, зважаючи на те, щзо для мовознавства XXI cm. характерна тендениія до аналізу живого спілкування, а безпосереднє усне мовне спілкування ще й досі є найважливімою сферою мови, уважаємо актуальним на сучасному етапі розвитку лінгвістики та перекладознавства дослідження американського сленгу та виокремлення його основних груп.

Мета статmі. У пропонованій статті маємо на меті дослідити специфіку використання американських сленгізмів.

Методи дослідження. У контексті студіювань використано описовий метод, що вможливив теоретичне узагальнення результатів, систематизацію та інтерпретацію функиіонування сленгових одиниць на певному етапі розвитку мови, метод суцільної вибірки для виокремлення сучасних американських сленгових одиниць із загальної кількості лексем, а також застосовано метод перекладацьких трансформачій для досягнення адекватного передавання змісту циих сленгізмів.

Основні результати дослідження. У науковій літературі виокремлюють переважно два види сленгу - загальний та спеціальний. Проте наразі немає одностайності щодо розрізнення спеціального сленгу. Дехто з дослідників вважає, що спеціальний сленг охоплює арго, кент, римований сленг, соиіальні жаргони та професійні говори, бек сленг. Інші переконані, що спеціальний сленг є специфічною лексикою та фразеологією соціальних жаргонів, професійних говорів та арго злочинного світу. Утім, на наше переконання, спеціальний сленг $є$ здебільшого національним феноменом, щуо не має відповідних аналогів в іншій культурі. Отже, в межах нашого дослідження до спеціального сленгу уналежнюємо слова $i$ словосполучення того чи того професійного або класового жаргону та виокремлюємо чотири його види: 1) римований; 2) мобільний; 3) студентський; 4) повсякденний молодіжний.

Висновки і перспективи. Питання перекладу сленгу є одним із найскладніших у теорії перекладу і водночас важливе для будь-якого перекладача, оскільки це пов'язане з цілою низкою елементів, зокрема, перекладаџьким різновидом країнознавства, культурою перекладача, наявністю еквівалентів, контексту, освіченістю та знаннями перекладача. На нашу думку, до перспективних напрямів належить вивчення гендерних особливостей у вживанні американського сленгу.

Ключові слова: сленгізми, римований сленг, мобільний сленг, студентський сленг, повсякденний молодіжний сленг.

\section{Abstract}

Background. Today, issues related to the study of slangisms are gaining new perspectives as slang is becoming an integral part of modern linguistics. Slangisms gradually become part of the language, function in it, and then disappear, giving opportunity new ones to exist (so new slang expressions can be formed). However, American slang is peculiar and unique, created in different social and age groups as a desire for brevity and expressiveness, sometimes as a protest against long words or as a desire to name an object or its properties in its own way. Therefore, considering the fact that linguistics of the 21st century is characterized by a tendency to analyze live communication, and oral language communication is still the most important aspect of language, we consider the study of American slang and the identification of its major groups to be relevant at the present stage of the development of linguistics and translation.

Purpose. In our scientific study we aim to investigate the specifics of using American slangisms.

Methods. In the context of studies, a descriptive method was used, which made it possible to theoretically generalize the results, systematize and interpret the functioning of slang units at a particular stage of language development, continuous sampling method was used to distinguish 


\section{Ukrainian sense. 2020. ISSN 2313-4437}

modern American slang units from the total number of lexemes as well as the method of translation transformations to achieve the adequate transmission of the content of these slangisms.

Results. Scientists mainly distinguish two types of slang - general and special. However, there is currently no unanimity in distinguishing between special slang. Some researchers believe that special slang encompasses argo, kent, rhyming slang, social jargon and professional speeches, back slang. Others are convinced that special slang is a specific vocabulary and phraseology of social jargon, professional speeches, and the argo of the criminal world. However, in our opinion, special slang is basically a national phenomenon that has no analogues in another culture. Therefore, within our study we distinguish 4 types of slang: 1) rhyming slang; 2) mobile slang; 3) student slang; 4) everyday slang.

Discussion. The issue of slang translation is one of the most difficult ones in translation theory. At the same time, it is important for any translator, because it is related to a number of elements, in particular, the translation variety of country studies, the culture of the translator, the availability of equivalents, context, education and knowledge of the translator. In our view, promising areas include the study of gender features in the use of American slang.

Keywords: slangisms, rhyming slang, mobile slang, student slang, everyday youth slang. 